DOI: $10.19195 / 2084-5065.43 .19$

\title{
Zbrodnia katyńska przed Europejskim Trybunałem Praw Człowieka - refleksje nad wyrokiem z 21 października 2013 roku
}

\author{
Witold KulesZA \\ Katedra Prawa Karnego \\ Uniwersytet Łódzki
}

\begin{abstract}
Wielce Szanownemu Jubilatowi, którego dzieła afirmują ideę sprawiedliwości i ukazuja węzłowe problemy jej urzeczywistnienia, pamiętny naszej nieprzedawnionej przyjaźni - drugi szkic o Zbrodni Nieukaranej-poświęcam.
\end{abstract}

W pierwszej Księdze jubileuszowej prof. Tomasza Kaczmarka przedstawiono zbrodnię katyńską w kontekście procesu norymberskiego, kończąc cytatem z pamiętnika amerykańskiego prokuratora wojskowego T. Taylora, który określił sprawę Katynia jako „polityczną brodawkę” na całym postępowaniu przed Trybunałem ${ }^{1}$. Współcześnie określenie to odnieść można także do wyroku Europejskiego Trybunału Praw Człowieka z 21 października 2013 r., albowiem oba trybunały uchyliły się od merytorycznego rozpatrzenia sprawy odpowiedzialności za zbrodnię katyńską i określenia konsekwencji, jakie powinna ponieść Rosja, której władze zdecydowały o jej dokonaniu. Brak jurydycznej kognicji w tym zakresie milcząco przyjął Trybunał Norymberski, natomiast Europejski Trybunał wypowiedział się w tej kwestii expressis verbis. Ponieważ wyrok strasburskiego Trybunału ma moc precedensu, przygnębiać musi refleksja, że w swej konsekwencji zamyka on sprawę zbrodni katyńskiej na forum międzynarodowej sprawiedliwości. Z tego względu wydaje się uzasadnioną próba spojrzenia na orzeczenie strasburskie z perspektywy procesu norymberskiego, ponieważ łączy je jurystyczna niemoc osądzenia tej zbrodni i państwa odpowiedzialnego za jej dokonanie.

1 W. Kulesza, Zbrodnia katyńska w procesie norymberskim - refleksje nad stenogramem rozprawy, [w:] Przestepstwo - kara - polityka kryminalna. Problemy tworzenia i funkcjonowania prawa. Ksiega jubileuszowa z okazji 70. rocznicy urodzin Profesora Tomasza Kaczmarka, red. J. Giezek, Kraków 2006, s. 422 n. 
W wyroku z 21 października 2013 r. Janowiec i inni przeciwko Rosji Europejski Trybunał Praw Człowieka, obradując jako Wielka Izba, orzekł w sprawie połączonych skarg (nr 55506/07 i 29520/09) 15 obywateli polskich, członków rodzin ofiar zamordowanych w wykonaniu decyzji z 5 marca 1940 r., przeciwko Federacji Rosyjskiej, którym Naczelna Prokuratura Wojskowa odmówiła dostępu do akt śledztwa nr 159 i postanowienia końcowego o jego umorzeniu z 21 września 2004 r., przekazania dokumentów dotyczących osób rozstrzelanych i ich rehabilitacji ${ }^{2}$. Odmowę udostępnienia odpisu postanowienia o umorzeniu śledztwa uzasadniono tym, że jest ono ściśle tajne. Rosyjski sąd wojskowy 14 października 2008 r., choć przyznał, że nazwiska krewnych osób skarżących znajdują się w sporządzonych przez NKWD wykazach więźniów obozów w Kozielsku, Starobielsku i Ostaszkowie, stwierdził jednak, że

śledztwo katyńskie [...] nie ustaliło losów tych osób. Odmowę rehabilitacji uzasadniono tym, że w śledztwie nie zdołano określić, który artykuł Kodeksu karnego z 1926 r. był podstawą ich represjonowania co uniemożliwiło ustalenie, czy osoby te były ofiarami represji politycznych, a tylko do takich osób znajduje zastosowanie ustawa z 1991 o rehabilitacji ${ }^{3}$.

Stanowisko to powtórzyło 29 stycznia 2009 r. Kolegium Wojskowe SN Federacji Rosyjskiej, dodając, że przestępstwo będące przedmiotem śledztwa, zakwalifikowane jako nadużycie władzy, przedawniło się po dziesięciu latach od jego popełnienia - w 1950 r. Sądy odrzucały także wniosek memoriału o odtajnienie postanowienia o umorzeniu postępowania karnego $\mathrm{nr} 159$, a odmowę podtrzymał Sąd Najwyższy 26 listopada 2011 r. Odmowy rosyjskich sądów, z jakimi spotykali się krewni ofiar i wspierający ich Memoriał, sprawiły, że po wyczerpaniu drogi krajowej ${ }^{4}$ zwrócili się oni do Strasburga, zarzucając władzom rosyjskim, że:

— nie dopełniły swoich obowiązków wynikających z aspektu proceduralnego deklaracji zawartej w art. 2 Konwencji o ochronie praw człowieka i podstawowych wolności z 1950 r. deklarującej prawo każdego człowieka do życia, który

2 Wielka Izba Trybunału orzekała na wniosek skarżących z 5 lipca 2012 r., którzy odwołali się od wyroku Izby z dnia 16 kwietnia 2012 r. wydanego w składzie siedmioosobowym, stwierdzającego, że nie była ona w stanie zbadać meritum sprawy przeciwko Rosji, która dopuściła się nieludzkiego i poniżającego traktowania (tylko) $10 \mathrm{z}$ nich, nie wywiązując się przy tym z obowiązku współdziałania z Trybunałem (§ 7).

${ }^{3}$ Ustawa o rehabilitacji z dnia 18 października $1991 \mathrm{r}$. definiuje w art. 1 represje polityczne jako wszelkie środki przymusu stosowane przez organy państwa z powodów politycznych, w tym pozbawienie życia lub wolności. Ustawa odnosi się także do cudzoziemców, którzy byli poddani represjom politycznym na terytorium Federacji Rosyjskiej po dniu 7 listopada 1917 r.

${ }^{4}$ Szczegółowo: I.C. Kamiński, ,,Skargi katyńskie” przed Europejskim Trybunałem Praw Człowieka w Strasburgu, [w:] Zbrodnia Katyńska. W kręgu prawdy i kłamstwa, red. S. Kalbarczyk, Warszawa 2009, s. 154; idem, Kto i jak może występować przed Europejskim Trybunatem Praw Człowieka w sprawie Zbrodni Katyńskiej, [w:] Zbrodnia katyńska. Naród, państwo, rodzina, red. M. Tarczyński, „Zeszyty Katyńskie” 2009, nr 24, s. 129; A. Gurjanow, Sprawa Katyńska w sądach rosyjskich 2007-2009, [w:] Zbrodnia katyńska. Naród..., s. 100. 
w rozumieniu procesowym wymagał przeprowadzenia właściwego i skutecznego śledztwa w sprawie śmierci ich krewnych;

- długo zaprzeczały faktom historycznym oraz zataiły informacje o losie ich bliskich, jak również udzielały lekceważących i sprzecznych odpowiedzi na wnioski o informacje, co stanowiło nieludzkie i poniżające traktowanie, sprzeczne $\mathrm{z}$ art. 3 konwencji 5 .

Rozpatrując argumenty podniesione przez skarżących, Europejski Trybunał nie zapoznał się z treścią postanowienia o umorzeniu śledztwa nr 159 z tego powodu, że pomimo kilkakrotnego żądania, rząd Rosji odmówił przedłożenia kopii tego dokumentu, twierdząc, iż według prawa krajowego ma on ściśle tajny charakter. Odmowę udostępnienia postanowienia kończącego umorzeniem rosyjskie śledztwo uzasadniono tym,

iż uznanie trzydziestu sześciu tomów akt oraz postanowienia z dnia 21 września 2004 r. za dokumenty „ściśle tajne” było zgodne z prawem, jako że zawierały one informacje dotyczące wywiadu, kontrwywiadu oraz działalności operacyjnej i zwiadowczej.

Zaznaczono, że klasyfikacja tych dokumentów jako tajnych została „sprawdzona i potwierdzona" przez Federalną Służbę Bezpieczeństwa, a następnie przez Sąd Miejski w Moskwie, w którego okręgu ma swą siedzibę Główna Prokuratura Wojskowa, oraz utrzymana orzeczeniem Sądu Najwyższego. Choć do kwestii tej Trybunał odniósł się na końcu swego wyroku, zostanie ona przedstawiona na początku poniższego omówienia treści jego rozstrzygnięcia.

Odnosząc się do argumentacji pozwanego rosyjskiego rządu, Trybunał odnotował, że wniosek o odtajnienie postanowienia o umorzeniu śledztwa nr 159 został przez Moskiewski Sąd Miejski oddalony z tym uzasadnieniem, że:

W śledztwie ujawniono działania wielu wymienionych z nazwiska wysokich urzędników ZSRR stanowiące nadużycie władzy w okolicznościach szczególnie obciążających, określonych w art. 193. 17 (b) Kodeksu karnego RFSRR. Sprawa karna w odniesieniu do tych urzędników została umorzona na podstawie art. 24 § 1 (4) rosyjskiego Kodeksu postępowania karnego (z tytułu śmierci osób winnych). W odniesieniu do pozostałych osób postępowanie zostało umorzone na podstawie art. $24 \S 1$ (2), (nie popełniono przestępstwa) (§ 64).

Dalej wskazano, że Federalna Służba Bezpieczeństwa sformułowała opinię, na podstawie której Naczelna Prokuratura Wojskowa nadała dokumentowi klauzulę „ściśle tajne”, co uczyniono, przywołując jako podstawę prawną przepisy ustawy o tajemnicy państwowej z 1993 r. obejmującą ,,informacje z dziedziny wywiadu, kontrwywiadu oraz działalności operacyjnej i zwiadowczej" (art. 4).

Trybunał przekonująco zakwestionował racje utajnienia dokumentów, konstatując, że „sądy krajowe nie przeprowadziły, żadnej rzeczowej analizy twierdzeń

5 Art. 3 Nikt nie może być poddany torturom ani nieludzkiemu lub poniżającemu traktowaniu albo karaniu. 
władzy wykonawczej, jakoby informacje zawarte w postanowieniu powinny pozostawać tajne ponad siedemdziesiąt lat od badanych wydarzeń". Zauważył jednocześnie, że: „Nie jest nawet pewne, czy Sąd Miejski zapoznał się z kopią raportu eksperckiego sporządzonego przez Federalną Służbę Bezpieczeństwa”. Podkreślone zostało, że sądy rosyjskie nie odniosły się do meritum argumentów stowarzyszenia Memoriał, które podnosiło, iż postanowienie zakończyło śledztwo w sprawie masowego mordu nieuzbrojonych więźniów, jednego z najcięższych naruszeń praw człowieka popełnionego na rozkaz najwyższych funkcjonariuszy sowieckich i jako takie nie podlegało utajnieniu, o czym stanowi art. 7 ustawy z 1993 r. o tajemnicy państwowej ${ }^{6}$. Trybunał stwierdził dalej, że żądany dokument „odnosił się do wydarzeń historycznych, których uczestnicy w większości wypadków już nie żyją, a który w żaden sposób nie mógł mieć wpływu na jakiekolwiek bieżące policyjne działania inwigilacyjne czy inne środki” (§ 127). Dlatego Trybunał słusznie nie przyjął argumentu, że przedłożenie mu żądanej kopii postanowienia z 21 września 2004 r. miałoby wpływ na bezpieczeństwo narodowe Rosji i uznał, iż jej rząd nie wywiązał się z obowiązków ciążących na nim na podstawie art. 38 konwencji (§ 151). Teza zamykająca streszczony w skrócie wywód, głosząca, że pozwane państwo nie wypełniło obowiązków wynikających z art. 38 konwencji ${ }^{7}$, została jednomyślnie przyjęta przez 17 sędziów Wielkiej Izby Trybunału.

W tym miejscu nasuwa się refleksja, że w procesie norymberskim rosyjscy prokuratorzy na poparcie sformułowanego przez nich w akcie oskarżenia głównych zbrodniarzy wojennych stwierdzili, że: „We wrześniu 1941 r. zamordowano 11 tys. polskich oficerów - jeńców wojennych w lesie katyńskim obok Smoleńska”, przedstawili — jak to określili — ,szczegółowy raport” z prac specjalnej komisji śledczej, zgłosili trzech świadków, którzy złożyli zeznania, a także oświadczyli, że są gotowi przedstawić dalszych 120 świadków, którzy potwierdzą, że to Niemcy dokonali zbrodni w Katyniu ${ }^{8}$.

Jeżeli współcześnie wyniki drugiego rosyjskiego śledztwa polegają na prawdzie, to skrywanie jej i odmowa udostępnienia poszukującym prawdy pod pozorem, że musi pozostać ściśle tajna ze względu na interes państwowy, wywołać musi refleksję, że w imię takiego właśnie interesu otwarcie głoszono w Norymberdze nieprawdę. Można by przeto oczekiwać, że Rosja skorzysta w Strasburgu z okazji do choćby częściowego naprawienia szkody wyrządzonej międzynarodowej sprawiedliwości w procesie norymberskim i udostępni także dokument kończący

${ }^{6}$ Art. 7 zastrzega, że nie mogą być sklasyfikowane jako tajemnica państwowa lub podlegać utajnieniu w szczególności informacje dotyczące naruszeń praw człowieka, a także naruszeń praw dokonanych przez władze lub urzędników państwowych.

7 Art. 38. Rozpatrywanie sprawy. Trybunał rozpatruje sprawę z udziałem przedstawicieli stron i, jeśli zachodzi potrzeba, podejmuje dochodzenie, a zainteresowane Wysokie Układające się Strony udzielą dla jego skutecznego przeprowadzenia wszelkich niezbędnych ułatwień.

8 Więcej W. Kulesza, Zbrodnia katyńska w procesie norymberskim..., s. 425. 
ponownie przeprowadzone śledztwo, który ze swej prawnej natury powinien zawierać kwintesencję prawdy o zbrodni, jej sprawcach i ich odpowiedzialności ${ }^{9}$. Na powstające w tym miejscu rozważań pytanie, ile prawdy może przypuszczalnie zawierać ów tajny dokument, trzeba poszukiwać odpowiedzi w tym, jak pozwana Rosja odniosła się do zarzutów w postępowaniu przed strasburskim Trybunałem.

Przedstawienie rozumowania Trybunału odnośnie do otwierającego skargę zarzutu wobec władz Rosji, że nie dopełniły swoich obowiązków wynikających z aspektu proceduralnego art. 2 konwencji, ponieważ nie przeprowadziły właściwego i skutecznego śledztwa w sprawie śmierci krewnych osób skarżących, wymaga z konieczności skrótu i zwrócenia uwagi tylko na najważniejsze jego aspekty.

Skarżący podnieśli, że nie przeprowadzono kompletnych badań wykopaliskowych w miejscu masowych grobów, odmówiono im statusu pokrzywdzonych w śledztwie, któremu nie postawiono za cel ustalenie sprawców okrucieństw i postawienie ich przed sądem, pomimo że dwóch wysokich funkcjonariuszy sowieckich związanych ze zbrodnią katyńską żyło jeszcze w latach $90 .{ }^{10}$ Skarżący zarzucili także władzom Rosji, że o 1803 osobach mówią nadal jako o ,zaginionych”, nie zaś zamordowanych ${ }^{11}$.

Podniesienie przed Trybunałem zarzutu zaniechania przeprowadzenia skutecznego śledztwa opierało się na założeniu, że Trybunał powinien posiadać jurys-

9 Sprawa wpływu Rosji na proces norymberski jest stale przedmiotem szczegółowych badań. Zob. I. Schulmeiter-Adre, Internationale Strafgerichtsbarkeit unter sowjetischem Einfluss. Der Beitrag der UdSSR zum Nürberger Hauptkriegsverbrecherprozess, Berlin 2016.

${ }_{10}$ Rosyjska prokuratura nie podała informacji o tym ilu wykonawców, bezpośrednio uczestniczących w mordowaniu jeńców i więźniów żyło w czasie, gdy wszczęto śledztwo. Przesłuchano w charakterze świadków dwóch z nich (M. Syromiatnikowa i I. Barinowa), a także jednego z naczelników NKWD — D. Tokariewa. Przypuszcza się, że żył w tym czasie także naczelnik P. Tichonow, nie podano jednak, czy został on przesłuchany. N. Pietrow, Kto zabijał Polaków strzałem w tyt głowy w Katyniu, Charkowie i Twerze, [w:] Zbrodnia katyńska. Naród..., s. 107.

11 Według oświadczenia złożonego przez przedstawicieli Głównej Prokuratury Wojskowej na rozprawie w dniu 18 marca 2009 r. przed Sądem Miejskim w Moskwie materiały ekshumacji przeprowadzonej w Katyniu w 1943 r. przez powołaną z niemieckiej inicjatywy komisję ekspertów nie zostały włączone do akt śledztwa nr 159. Dokumentacja prac komisji, która ekshumowała 4243 zwłoki polskich oficerów, została opublikowana w książce Amtliches Material zum massenmord von Katyn. W załączniku podano nazwiska tych ofiar, które zostały zidentyfikowane. Publikacja ta nie została włączona do dowodów w procesie norymberskim i nie była traktowana jako dowód w postępowaniach sądowych prowadzonych na podstawie przepisów ustawy z $1991 \mathrm{r}$. O rehabilitacji ofiar represji politycznych. W konsekwencji możliwe było odrzucanie wniosków o rehabilitacje zamordowanych polskich oficerów, których nazwiska znajdują się na niemieckiej liście identyfikacyjnej, z tym uzasadnieniem, że w rosyjskiej dokumentacji „,brak personalnych decyzji o represjonowaniu każdego z jeńców”. Jednakże w latach 1990-1994 niemiecka dokumentacja znajdowała się w aktach rosyjskiego śledztwa kierowanego przez prok. A. Jabłokowa (następnie służbowo odsuniętego) i jako taka stanowiła dowód sowieckich represji. Moskiewski Sąd Miejski nie dopuścił jednak zeznań A. Jabłokowa w tej kwestii. A. Gurjanow, op. cit., s. 107. 
dykcję do zbadania jego treści, mimo że sam akt zbrodni katyńskiej popełnionej w 1940 r. pozostaje formalnie poza zasięgiem temporalnym konwencji z $1950 \mathrm{r}$. Jednakże zbrodnia ta ze względu na jej rozmiary i ciężar gwałciła fundamentalne wartości, o których mowa w preambule konwencji, co powinno nadać współcześnie Trybunałowi jurysdykcję ratione temporis dla oceny obowiązku Rosji przeprowadzenia skutecznego śledztwa i ustalenia konsekwencji jego niedopełnienia $(\S 114,115)$.

Punktem wyjścia dla odpowiedzi na skargę i sformułowania swego stanowiska przez rząd Rosji było stwierdzenie, że naruszenie art. 2 nie istniało de jure, skoro „wydarzenia katyńskie” (tak strona rosyjska określa zbrodnię katyńską) poprzedziły przyjęcie konwencji 4 listopada 1950 r. o 10 lat, a jej ratyfikację przez Rosję 5 maja 1998 r. — o 58 lat. Ponieważ w czasie „wydarzeń” konwencja nie obowiązywała, nie miało miejsca ,»prawnie istniejące « naruszenie art. $2 \mathrm{w}$ jego wymiarze materialnym", a tylko takie mogłoby uruchomić obowiązek proceduralny Rosji przeprowadzenia śledztwa. Odmówienie Trybunałowi właściwości ratione materiae oznaczało - według referowanego stanowiska — że nie może on „określać masakrę katyńską jako »zbrodnię wojenną《 z punktu widzenia międzynarodowego prawa humanitarnego”. Zaznaczono, że „co najmniej” do 1945 r. nie istniał jakikolwiek wiążący przepis prawa międzynarodowego, który zawierał definicję zbrodni wojennych lub zbrodni przeciwko ludzkości, lub określał odpowiedzialność za ich popełnienie i ściganie. Podkreślone zostało stałe stanowisko Rosji, że „zasięg Karty norymberskiej”, czyli statutu Międzynarodowego Trybunału Wojskowego z 8 sierpnia 1945 r., która zawierała definicje takich zbrodni, był ograniczony do postępowań przed Międzynarodowym Trybunałem Wojskowym przeciwko głównym zbrodniarzom wojennym należącym do europejskich państw Osi.

Zdumiewa otwartość, z jaką rząd Rosji sformułował swój pogląd prawny na zbrodnię katyńską, niezmiennie używając eufemizmu „wydarzenia katyńskie” i kategorycznie negując dokonanie kwalifikacji tej zbrodni na gruncie prawa międzynarodowego, z tym zastrzeżeniem, że byłoby to możliwe tylko, gdyby zdołano obciążyć Niemców odpowiedzialnością za jej popełnienie ${ }^{12}$. Trybunał tak streścił rosyjskie stanowisko:

12 Prok. wojskowy J. Pokrowski wywodził w trakcie procesu norymberskiego: „My stwierdziliśmy, w akcie oskarżenia, że jednym z najważniejszych aktów przestępczych, za które odpowiedzialni są główni przestępcy wojenni, była masowa egzekucja polskich jeńców wojennych rozstrzelanych w lesie katyńskim w pobliżu Smoleńska przez niemieckich faszystowskich najeźdźców”. Trial of The Major War Ciminals before International Military Tribunal. Official Text, Nuremberg 1947, t. VII, s. 428. Rosyjskimi prokuratorami i sędziami delegowanymi do procesu kierowano instrukcjami wydawanymi przez powołaną w Moskwie „Komisję rządową ds. procesu norymberskiego", której członkami byli między innymi dwaj zastępcy Ł. Berii — B. Kobułow i W. Mierkułow. Uznać to trzeba za szczególną perfidię, ponieważ to oni zorganizowali wykonanie 
Rząd konkludował, iż prawo międzynarodowe, takie jak ono obowiązywało w $1940 \mathrm{r}$. nie dostarczało wystarczającej podstawy dla określenia „wydarzeń katyńskich” zbrodnią wojenną, zbrodnią przeciwko ludzkości lub ludobójstwem, chyba że dałoby się je przypisać głównym zbrodniarzom wojennym osi europejskiej i podlegałyby one jurysdykcji Trybunału Norymberskiego (§ 110).

Znaczy to, że gdyby rosyjski plan przypisania zbrodni katyńskiej Niemcom w procesie norymberskim powiódł się, to kwalifikacja zbrodni katyńskiej jako zbrodni wojennej i jednocześnie zbrodni przeciwko ludzkości, stanowiącej akt ludobójstwa dokonanego na obywatelach pokonanej w 1939 r. Polski, nie budziłaby żadnych zastrzeżeń prawnych. Innymi słowy - historyczne fałszerstwo stałoby się w ten sposób jurystyczną prawdą.

Nasuwa się w tym miejscu refleksja, że współczesna Rosja traktuje porozumienie londyńskie z 8 sierpnia 1945 r o powołaniu Międzynarodowego Trybunału Wojskowego i jego statut jako źródło przysługującego jej swego rodzaju historycznego i prawnego immunitetu, który wyklucza ocenę sowieckich masowych mordów na polskich jeńcach wojennych i wywózki ich rodzin w kategoriach prawa międzynarodowego. Według rosyjskiego poglądu pojęcia zbrodni przeciwko pokojowi, zbrodni wojennych i zbrodni przeciwko ludzkości miały zostać w statucie Trybunału norymberskiego niejako „,zarezerwowane”, także na przyszłość, tylko i wyłącznie do zbrodni popełnionych przez III Rzeszę Niemiecką.

Zauważyć w tym miejscu trzeba, że rząd Rosji pomija fakt, iż zbrodnia katyńska stanowiła pogwałcenie obwiązujących w czasie jej popełnienia praw i zwyczajów wojennych, a w szczególności uregulowań IV konwencji haskiej z 18 października 1907 r., dotyczących praw i zwyczajów wojny lądowej oraz konwencji genewskiej z 27 lipca 1929 r. odnoszącej się do traktowania jeńców wojennych. Przypomnieć przeto trzeba, że w procesie norymberskim obrona oskarżonych w nim głównych przestępców wojennych podnosiła, iż nie można oskarżać Niemców o zbrodnie wojenne popełnione na jeńcach rosyjskich, ponieważ Związek Sowiecki nie przystąpił przed wybuchem wojny do konwencji genewskiej z $1929 \mathrm{r}$. o traktowaniu jeńców wojennych i dlatego nie obowiązywała ona w stosunkach niemiecko-rosyjskich. Jednak Trybunał w Norymberdze obronę tą odrzucił kategorycznym stwierdzeniem, że z prawnego punktu widzenia jest całkowicie zbędne wdawać się w rozważanie takiego argumentu, ponieważ chodziło o pogwałcenie powszechnie obowiązujących zasad zwyczajowego prawa międzynarodowego istniejących obok norm traktatowych, te natomiast były w istocie jedynie spisanymi zasadami zwyczajowymi ${ }^{13}$. Takie stanowisko stwierdzające, że rosyjscy jeńcy wojenni podlegali ochronie prawa międzynarodowego (pomimo niepodpisania

decyzji z 5 marca 1941 r. o rozstrzelaniu polskich jeńców wojennych i więźniów. Działanie tej komisji ujawniła N. Lebiediewa, Katyn: priestuplienie protiw czełowieczestwa, Moskwa 1994, s. 299.

13 T. Cyprian, J. Sawicki, Prawo norymberskie. Bilans i perspektywy, Warszawa-Kraków 1948, s. 279. 
przez Rosję konwencji genewskiej) zajmowali także rosyjscy oskarżyciele w procesie norymberskim, o czym świadczy wywód prokuratora Pokrowskiego, który opisywał niemieckie zbrodnie dokonywane na żołnierzach rosyjskich i stwierdzał: „W ten sposób bolszewicki żołnierz utracił swe prawo do bycia traktowanym jako prawdziwy żołnierz i w zgodzie z zasadami konwencji genewskiej”"14.

Wrażenie, że Rosja rości sobie prawo do szczególnego immunitetu wykluczającego ocenę zbrodni katyńskiej w kategoriach prawa międzynarodowego, umacnia się przy lekturze kolejnych fragmentów wyroku Europejskiego Trybunału. Rząd Rosji ujawnił, że „na poziomie krajowym śledztwo toczyło się w kierunku przestępstwa karnego na podstawie art. 193-17 (b) kodeksu karnego RSRRR z 1926 r.", to jest w sprawie nadużycia władzy powodującego poważne konsekwencje i popełnionego w okolicznościach zaostrzających karę, które przedawnia się $\mathrm{z}$ upływem 10 lat $^{15}$.

Zarówno przedawnienie, jak i to, że ,oficerowie NKWD zmarli przed wszczęciem śledztwa", stanowiło według prawa krajowego odrębne podstawy prawne uniemożliwiające wszczęcie lub prowadzenie przeciwko nim postępowania karnego. Przypomnieć trzeba, iż w przytoczonym orzeczeniu Sądu Miejskiego w Moskwie z 2 listopada 2010 r., który oddalił wniosek o odtajnienie postanowienia kończącego śledztwo, napisano, że ujawniono w nim „działania wielu wymienionych z nazwiska wysokich urzędników ZSRR stanowiące nadużycie władzy", w stosunku do których umorzono postępowanie z powodu ich śmierci. Dalej podano,

14 Trial of The Major..., s. 424.

15 W wyroku Trybunału nie została przytoczona treść art. 193-17 b rosyjskiego kodeksu karnego z 1926 r., który był podstawą prowadzonego śledztwa po tym, jak Główna Prokuratura Wojskowa unieważniła opinię powołanej przez siebie komisji ekspertów z 2 sierpnia 1993 r. stwierdzającą, że zbrodnia katyńska stanowiła akt ludobójstwa. Dlatego potrzebne wydaje się być zacytowanie tego przepisu otwierającego rozdział zatytułowany „Przestępstwa wojskowe”, opisującego w punkcie pierwszym (a) przestępstwo jako: „Nadużycie władzy, przekroczenie władzy, bezczynność władzy, a także niedbałe odnoszenie się do służby przez osobę wchodzącą w skład dowództwa Robotniczo-Chłopskiej Czerwonej Armii, jeżeli działania takie były dokonywane systematycznie lub dla korzyści osobistych, lub dla innych osobistych interesów, jak również jeżeli ich następstwem była dezorganizacja powierzonych jej sił lub zleconego zadania, lub rozgłoszenie tajemnic wojskowych, lub inne ciężkie następstwa, lub choćby nie miały wskazanych następstw lecz ze świadomością, że mogły je mieć, lub dokonane zostały w czasie wojny, lub w sytuacji bojowej, pociąga za sobą pozbawienie wolności na czas nie krótszy od sześciu miesięcy”. W punkcie drugim (b) napisano: „Takie działania, przy obecności szczególnie obciążających okoliczności pociągają za sobą surowszy wymiar kary". Zdaniem A. Gurjanowa powołanie tego przepisu dotyczącego tylko osób wojskowych jako podstawy kwalifikacji prawnokarnej śledztwa pozwoliło na wyłączenie Stalina z kręgu podejrzanych o popełnienie tego przestępstwa i ograniczenie go do poszczególnych osób z kierownictwa NKWD: Berii i „trójki” wykonawczej polecenia z 5 marca 1940 r. - Mierkułowa, Kobułowa i Basztakowa. A. Gurjanow, op. cit., s. 115. Jeżeli postanowienie o umorzeniu śledztwa uwalnia Stalina, jako niepodlegającego przytoczonemu powyżej przepisowi, od odpowiedzialności za zbrodnię katyńską, to skrywanie przez Rosję tego historycznego i prawniczego absurdu nabiera dodatkowego znaczenia. 
że w odniesieniu do pozostałych osób postępowanie zostało umorzone, ponieważ ich czyny „nie stanowiły przestępstwa”, nie wskazując przy tym podstawy prawnej takiego stwierdzenia. Można przypuszczać, że przyjęto generalną zasadę, na której opierało się radzieckie wojskowe prawo karne, głoszącą, że wykonawca rozkazu nie popełnia przestępstwa, gdyż każdy rozkaz jest „okolicznością wyłączającą bezprawność czynu dokonanego przez podwładnego”, to jest „prawem dla podwładnych”, nie wolno im go oceniać i „musi być wykonany bezwzględnie, ściśle i w terminie”"16. Znaczyło to, że „wykonanie rozkazu przełożonego nie zależy w żadnym wypadku od zdania podwładnego co do użyteczności, celowości lub legalności otrzymanego przezeń rozkazu”. Zaznaczano także, iż z zasady bezwzględnego posłuszeństwa podwładnego, „obowiązującego w Siłach Zbrojnych ZSRR” wynika „obciążenie odpowiedzialnością przełożonego, który wydał rozkaz za następstwa jego wykonania" ${ }^{17}$. Zasada ta ma kluczowe znaczenie w sprawie, ponieważ, jak zaznaczono w piśmiennictwie art. 18 ustawy z $1991 \mathrm{r}$. O rehabilitacji ofiar represji politycznych, przewiduje odpowiedzialność karną osób, które dopuściły się przestępstw jako uczestniczący w represjach politycznych, w tym funkcjonariuszy NKWD, prokuratorów, sędziów, a także członków specjalnych komisji „dwójek” i „trójek”18. Jednakże ówczesna zasada bezwzględnego posłuszeństwa i współczesny zakaz retroaktywności, ustanowiony w art. 10 KK Federacji Rosyjskiej z 1996 r., sprawiają łącznie, że przepis ten pozostał martwy, jak również nie znajdują zastosowania do „wydarzeń katyńskich” ani

16 W.M. Czchikwadze, Radzieckie prawo karne wojskowe. Część ogólna, Warszawa 1952, s. 182. Autor podkreślał, że „nie może być tolerowane i bezwzględnie jest niedopuszczalne jakiekolwiek usiłowanie krytykowania rozkazu" (s. 184). Nakaz bezwzględnego posłuszeństwa wobec przełożonych pod groźbą kary za niewykonanie ich rozkazów wpisany został do ustawy o przestępstwach wojskowych z 1927 r. (art. 2). Osoby inne aniżeli wojskowe podlegały karom przewidzianym w tej ustawie, jeżeli miał miejsce ich współudział w przestępstwach wojskowych. Konsekwencje nieposłuszeństwa określał art. 193-2a k.k. z 1926 r: „Niewykonanie wydanego służbowo polecenia karane jest pozbawieniem wolności na czas do pięciu lat”. W 1935 r. podwyższona została kara pozbawienia wolności „na czas nie krótszy niż trzy lata” za niewykonanie rozkazu przez osobę należącą do kadry przełożonych, a w czasie wojny lub w przypadku okoliczności obciążających ustanowione zostało „rozstrzelanie i konfiskata mienia”, art. 193-2d. Przypuszczać można, że nakaz bezwarunkowego posłuszeństwo rozkazowi uznała rosyjska prokuratura w postanowieniu końcowym za podstawę umorzenia postępowania wobec wszystkich 125 wykonawców zleconych mordów, wymienionych w rozkazie NKWD ZSRR nr 001365 r. z 26 października 1940 r., nagradzającym ich za „,pomyślne wykonanie zadań specjalnych”. To, że prokuratura odmówiła ogłoszenia listy bezpośrednich wykonawców zbrodni, określa N. Pietrow jako „zupełnie absurdalne, ponieważ ich nazwiska są od dawna znane historykom i zostały opublikowane w zbiorze dokumentów dotyczących Katynia", idem, op. cit., s. 176. Wydaje się, że rosyjskim władzom chodzi o ukrycie racji umorzenia, jaką jest uznanie za wiążące zbrodniczych rozkazów, którymi polecono im wykonanie „zadań specjalnych”.

17 W.M. Czchikwadze, op. cit., s. 185.

18 L.B. Obidina, Kurzbericht - Rußlad, Strafrecht in Reaktion auf Systemunrecht. Vergleichende Einblicke in Transitionsprozesse, red. A. Ester, J.Arnold, Freiburg in Breisgau 2000, s. 250. 
art. 356 zakazujący „okrutnego traktowania jeńców wojennych i ludności cywilnej”, ani art. 357 traktujący o ludobójstwie [,genocid”], mimo że przestępstwa te nie ulegają przedawnieniu (art. 78-5). Oznacza to, że funkcjonariusze NKWD wszystkich szczebli, prokuratury i sądów przeprowadzających represje na rozkaz lub polecenie władzy są współcześnie traktowani jako wykonawcy, którzy wówczas nie popełniali przestępstw ${ }^{19}$. Przypomnieć przeto trzeba, że gdy w procesie norymberskim usiłowano przypisać Niemcom zbrodnię katyńską, obowiązywała zasada: „Okoliczność, że oskarżony działał w wykonaniu rozkazu swego rządu lub swego przełożonego, nie zwalnia go od odpowiedzialności [...]" (art. 8 Statutu Międzynarodowego Trybunału Wojskowego) ${ }^{20}$.

19 Z perspektywy rozwiązania odnośnie do mocy wiążącej rozkazu wojskowego przyjętego w obowiązującym kodeksie karnym Rosyjskiej Federacji z 1996 r. stwierdza się, że postanowienie ustawy dyscyplinarnej sowieckiej armii głoszące: „Rozkaz naczelnika — prawo dla podwładnego, powinien być wykonany bezwzględnie, ściśle i w czasie" oznaczało, że podwładny ponosił odpowiedzialność za niewykonanie rozkazu ,jakim by on nie był”. W art. 42 obowiązującego kodeksu karnego przyjęto zasadę, że nie popełnia przestępstwa wykonawca „wiążącego rozkazu lub polecenia”, za które uważa się „legalne” [zakonnyje], to jest wydane w ramach kompetencji danego naczelnika i we właściwej formie. Wydanie przez naczelnika rozkazu lub polecenia wykraczającego poza przysługujące mu kompetencje pociąga za sobą, w najpoważniejszych przypadkach, jego odpowiedzialność karną za przestępstwo przekroczenia uprawnień (art. 286). Ponosi jednakże odpowiedzialność karną osoba, jeżeli popełnia ona umyślnie przestępstwo, wykonując oczywiście nielegalny [zawiedomo niezakonnyj] rozkaz lub polecenie. W takim przypadku odpowiedzialności karnej podlega zarówno naczelnik, który wydał taki rozkaz, jak i jego wykonawca, „,chociaż głównym przestępcą jawić się będzie naczelnik”. Niewykonanie oczywiście nielegalnego rozkazu lub polecenia „wyklucza odpowiedzialność karną za nieposłuszeństwo”. W innych przypadkach nieposłuszeństwo stanowi przestępstwo niewykonania rozkazu i podlega karze na mocy art. 332 tego kodeksu. Kommientar k Ugołownomu kodeksu Rossijskoj Fiederacii, red. B.M. Lebiediewa, Moskwa 2004, s. 109-111.

20 Stanowisko prokuratorów Instytutu Pamięci Narodowej — Komisji Ścigania Zbrodni przeciwko Narodowi Polskiemu opierało się na założeniu, że zasady prawa norymberskiego, jak też przyjęte w polskim prawie karnym i orzecznictwie sądowym dla osądzenia sprawców zbrodni nazistowskich powinny zostać odniesione także do sprawców Zbrodni Katyńskiej. Znaczy to, że za tę zbrodnię ponoszą odpowiedzialność zarówno wydający rozkazy i polecenia, jak i sprawcy przekazujący te rozkazy innym współdziałającym, także ci, którzy sporządzają listy z nazwiskami osób przeznaczonych do rozstrzelania, konwojenci transportujący ofiary na miejsce stracenia, ci, którzy pilnują ofiary na miejscu egzekucji, i bezpośredni sprawcy zabójstw. W celu ustalenia sprawców zbrodni katyńskiej dokonywanych w wykonaniu polecenia z 5 marca 1940 r. Minister Sprawiedliwości RP zwrócił się 27 sierpnia 2001 r. do Prokuratora Generalnego Federacji Rosyjskiej o ,przedstawienie stronie polskiej schematu przekazywania decyzji z 5 marca 1944 r. ze wskazaniem jednostek organizacyjnych NKWD i innych, a także ich składów osobowych, które uczestniczyły w wykonaniu tej decyzji”, w tym funkcjonariuszy, którzy uczestniczyli w konwojowaniu jeńców do miejsca kaźni, brali udział w egzekucji, transportowaniu zwłok i ich grzebaniu. Prośba obejmowała także informację, czy zidentyfikowano żyjących wykonawców zbrodni i czy odebrano od nich relacje i w jakim charakterze. Polska prośba nie została spełniona przez stronę rosyjską. 
Rząd Rosji podkreślił, że śledztwo w sprawie karnej nr 159 było prowadzone „z naruszeniem wymogów postępowania karnego, z powodów politycznych, jako gest dobrej woli wobec władz polskich". Także na wniosek polskich władz rosyjscy śledczy mieli dokonać analizy — jak napisano:

wersji o ludobójstwie [...] [i] ustalili, że nie doszło do popełnienia takiej zbrodni, ponieważ podejrzani mieli raczej jedynie kryminalne motywy, niż zamiar wyniszczenia w całości lub w części grupy narodowej, etnicznej, rasowej lub religijnej (zgodnie z definicją art. 2 lub 3 Konwencji o zapobieganiu i karaniu zbrodni ludobójstwa z dnia 9 grudnia 1948 r. $(\S 110)^{21}$.

Nie podano jednak, w oparciu o jakie dowody ustalono „raczej kryminalne motywy" podejrzanych, co jest kwestią zasadniczą odnośnie do kwalifikacji prawnokarnej, ponieważ w przygotowanej przez Berię uchwale podpisanej przez Stalina i czterech członków politbiura napisano o 22 tys. polskich jeńcach wojen-

${ }^{21}$ Zasadnicze różnice stanowisk i ocen prawnokarnych między prokuratorami polskimi i rosyjskimi odnośnie do zbrodni katyńskiej ujawnione zostały w trakcie bezpośrednich rozmów w dniu 4 sierpnia 2004 r. w siedzibie Naczelnej Prokuratury Wojskowej w Moskwie. Prokuratorzy Instytutu Pamięci Narodowej — Komisji Ścigania Zbrodni przeciwko Narodowi Polskiemu przedstawili uzasadnienie dla oceny zmordowania prawie 22 tys. polskich jeńców wojennych i więźniów w kategoriach zbrodni wojennej i zbrodni przeciwko ludzkości, a także ludobójstwa. Rosyjscy prokuratorzy podnieśli jako argument, że liczba pozbawionych życia nie jest wystarczająca, aby mówić o ludobójstwie, ponieważ w tym czasie w sowieckiej niewoli znajdowało się 240 tys. Polaków. Strona rosyjska nie odpowiedziała na pytania o przyjętą w śledztwie nr 159 kwalifikację prawnokarną zbrodni katyńskiej, nie odniosła się także do zagadnienia wpływu rozkazu wojskowego i polecenia władzy państwowej na odpowiedzialność karną organizatorów oraz bezpośrednich wykonawców. Stwierdzono natomiast, że „nie jest racjonalne” oczekiwanie na postawienie przed sądem żyjących wykonawców zbrodni. Zapowiedziano, że śledztwo zmierza ku końcowi i zadeklarowano przekazanie kopii wszystkich stu kilkudziesięciu tomów akt. O umorzeniu śledztwa nr 159 (21 września 2004 r.) nie powiadomiono jednakże strony polskiej, ponieważ, jak później wyjaśniano, treść tego dokumentu końcowego włącznie z jego tytułem i datą została objęta klauzulą „ściśle tajne”. Brak perspektyw na współpracę z rosyjską prokuraturą, która odmawiała udostępnienia części akt śledztwa i postanowienia o jego umorzeniu, był racją wszczęcia 30 listopada 2004 r. przez prokuratorów Komisji Ścigania Zbrodni przeciwko Narodowi Polskiemu śledztwa w sprawie Zbrodni Katyńskiej, to jest dokonanych w celu wyniszczenia części grupy narodowościowej zabójstw co najmniej 21768 polskich obywateli, wśród których znajdowali się w przeważającej części Polacy, lecz także Żydzi, Ukraińcy i Białorusini. Przyjęto za podstawę kwalifikacji prawnokarnej stwierdzenie, że zbrodnia katyńska stanowiła pogwałcenie obwiązujących w czasie jej popełnienia praw i zwyczajów wojennych, a w szczególności uregulowań IV konwencji haskiej z 18 października 1907 r. dotyczących praw i zwyczajów wojny lądowej oraz konwencji genewskiej z 27 lipca 1929 r. odnoszącej się do traktowania jeńców wojennych. Uznano, że zbrodnia katyńska podlega także ocenie w kategoriach zbrodni przeciwko ludzkości w najcięższej postaci — ludobójstwa, dlatego że plan sowieckich władz obejmował rozstrzelanie uwięzionych i równoczesne deportowanie ich rodzin w stepy Kazachstanu, co ze względu na panujące tam warunki zagrażające życiu oznaczało eksterminację całej grupy uznanej przez sowieckie władze za „obywateli byłego państwa polskiego". Decyzję o zesłaniu 22-25 tys. rodzin podjęło Biuro Polityczne 2 marca 1940 r., a więc trzy dni przed podpisaniem polecenia rozstrzelania ich bliskich. W wykonaniu tej decyzji deportowano w głąb ZSRR ponad 60 tys. osób. 
nych, których nakazano rozstrzelać: „Wszyscy oni są zawziętymi wrogami władzy sowieckiej, pełnymi nienawiści do ustroju sowieckiego". Twierdzenie o kryminalnych motywach sprawców ma - jak się wydaje — uzasadniać odmowę objęcia ofiar zbrodni katyńskiej postanowieniami o rehabilitacji tych, których zamordowano w aktach represji politycznych. Nie podano jednak żadnych nazwisk podejrzanych kierujących się taką kryminalną motywacją i mimo że — jak można przypuszczać - wymienione są one w zamykającym śledztwo postanowieniu o jego umorzeniu, to jednak pozostaną „ściśle tajne”, tak jak cały dokument, którego kopii wielokrotnie i bezskutecznie żądał Trybunał. Może to oznaczać, że ówcześni sprawcy o kryminalnej mentalności są współcześnie nadal chronieni ze względu na interes państwowy Rosji jako ci, którzy dopuścili się tylko przestępstwa krajowego nadużycia władzy, nie zaś zbrodni w rozumieniu prawa międzynarodowego.

Zauważyć trzeba, że przyjęta przez współczesną Rosję kwalifikacja prawna „wydarzeń katyńskich” w kategoriach zwykłego nadużycia władzy dokonanego przez kilka osób z kierownictwa NKWD i uwolnienie wszystkich podległych im wykonawców jako pospolitych „ślepych bagnetów” stanowi oczywiste pomniejszanie znaczenia tej zbrodni, a więc jej bagatelizowanie. Odnotować trzeba, że takie samo zachowanie w odniesieniu do zbrodni nazistowskich stanowi współcześnie przestępstwo według niemieckiego prawa karnego ${ }^{22}$.

W odniesieniu do zarzutu niedopełnienia proceduralnego obowiązku przeprowadzenia śledztwa wynikającego z art. 2 konwencji Rząd Rosji powtórzył, że śledztwo w sprawie karnej nr 159 nie było prowadzone z przyczyn prawnych, gdyż przedawnienie przestępstwa przekroczenia władzy (po 10 latach, czyli w 1950 r.), a także śmierć podejrzanych stanowiły zasadnicze przeszkody prawne dla jego wszczęcia i kontynuowania. Powtórzone zostało także, iż śledztwo to „było przeprowadzone z powodów politycznych jako gest dobrej woli” i dlatego nie może podlegać ocenie z perspektywy wymogów proceduralnych art. 2 konwencji. Podniesione zostało, że tylko te wydarzenia, które miały miejsce po przyjęciu przez Rosję Konwencji 5 maja 1998 r., mogłyby wywołać jakiekolwiek obowiązki proceduralne. Stwierdzono równocześnie, że od władz rosyjskich nie można było racjonalnie oczekiwać przeprowadzenia skutecznego śledztwa 58 lat po wydarzeniach, kiedy świadkowie już zmarli, a kluczowe dokumenty zostały zniszczone $(\S 111)^{23}$.

22 Wprowadzony w 1994 r. przepis $§ 130$ (3) StGB opisuje czyn zabroniony jako publiczne lub na zgromadzeniu pochwalanie, zaprzeczanie lub pomniejszanie ludobójstwa dokonanego pod panowaniem narodowego socjalizmu. Więcej W. Kulesza, ,Kłamstwo o Auschwitz” jako czyn zabroniony w polskim i niemieckim prawie karnym, [w:] Aktualne problemy prawa karnego. Ksiegga pamiatkowa z okazji Jubileuszu 70. urodzin Profesora Andrzeja J. Szwarca, red. Ł. Pohl, Poznań 2009, s. 303.

23 O zniszczeniu dokumentów dotyczących egzekucji 21857 jeńców wojennych i innych osób „z byłej Polski burżuazyjnej” informował Komitet Bezpieczeństwa Państwowego (KGB) w piśmie do Chruszczowa 5 marca 1959 r. Pismo to zostało oficjalnie podane do wiadomości 
Powtórzyć w tym miejscu trzeba, że pierwsze śledztwo przeprowadzono w styczniu 1944 r., a jego fałszywe rezultaty bezskutecznie przedstawiono Trybunałowi w Norymberdze. Rezultaty tego śledztwa prokurator Pokrowski przedstawił 14 lutego 1946 r. w procesie norymberskim, mówiąc, że zawiera je „precyzyjny i szczegółowy dokument” ukazujący ,wyniki ustaleń i śledczego zbadania zgodnie z dyrektywą Nadzwyczajnej Komisji Państwowej Związku Sowieckiego, w której skład weszli akademicy Burdenko, Aleksy Tołstoj i metropolita Mikołaj”24.

W kwestii powstania obowiązku proceduralnego, czyli prowadzenia śledztwa, rząd Rosji wytknął Trybunałowi, że nie posiada on jurysdykcji do analizy tego zagadnienia i zbadania okoliczności śmierci, które uruchomiłyby taki obowiązek, ponieważ fakt śmierci miał miejsce przed datą przyjęcia konwencji przez Rosję — 5 maja 1998 r. Obowiązek proceduralny — twierdzono — musi podlegać ograniczeniom po to, aby uniknąć „trudnego do przewidzenia rozszerzenia jurysdykcji Trybunału i zasięgu konwencji” (przez cofanie się do odległej przeszłości). Dlatego upływ czasu od śmierci „musi być racjonalnie krótki, a taki nie był w przedmiotowej sprawie". Ponadto ocenie może podlegać śledztwo, w którym znacząca część czynności została podjęta po dacie ratyfikacji, natomiast w śledztwie w sprawie „wydarzeń katyńskich” najważniejsze kroki procesowe uczyniono w latach 1990-1995, a żaden relewantny nowy materiał nie pojawił się po ratyfikacji. W konkluzji stanowiska rosyjskiego rządu stwierdzono, że Trybunał strasburski nie ma jurysdykcji ani ratione temporis, ani ratione materiae do oceny „wydarzeń katyńskich" z punktu widzenia międzynarodowego prawa humanitarnego (§ 112).

Trybunał rozpoczął swe rozważania od zbadania, czy jego jurysdykcja temporalna obejmuje rozpatrzenie meritum skargi na rząd Rosji, że nie dopełnił on wynikającego $\mathrm{z}$ art. 2 konwencji obowiązku proceduralnego przeprowadzenia skutecznego śledztwa. W punkcie wyjścia Trybunał stwierdził, że postanowienia konwencji nie wiążą strony w zakresie aktu lub faktu, który przestał istnieć przed „datą graniczną", to jest przed ratyfikacją konwencji przez jej stronę. Właściwość temporalna Trybunału obejmuje czynności i zaniechania natury proceduralnej, które nastąpiły lub powinny były nastąpić po wejściu w życie konwencji w stosunku do pozwanego rządu. Zaznaczone jednocześnie zostało, że Trybunał orzekał w wielu sprawach, w których same ,fakty odnoszące się do aspektu materialnego art. 2 lub 3 pozostawały poza jego właściwością temporalną, podczas gdy fakty związane $\mathrm{z}$ aspektem proceduralnym, to jest postępowaniem późniejszym mieściły się przynajmniej częściowo w zakresie jego właściwości” (§ 131 ${ }^{25}$.

publicznej 28 kwietnia 2010 r. za pośrednictwem strony internetowej Archiwów Państwowych Federacji Rosyjskiej.

24 Trial of The Major..., s. 428.

${ }^{25}$ W tym miejscu wywodu Trybunał wskazał swój wyrok w sprawie Šilih przeciwko Słowenii nr 71463/01 z dnia 9 kwietnia 2009 r., w którym znajduje się opis orzecznictwa odnoszącego się do 
Szczególnego znaczenia nabiera sformułowana przez Trybunał definicja „czynności natury proceduralnej”, które ma obowiązek wykonać państwo-strona konwencji. Napisano, że

pod pojęciem „czynności natury proceduralnej” należy rozumieć czynności nierozerwalnie związane z obowiązkiem proceduralnym wynikającym z art. 2 lub w zależności od sprawy, art. 3 Konwencji, to znaczy podjęte w ramach postępowania karnego, cywilnego, administracyjnego lub dyscyplinarnego, które powinno doprowadzić do wykrycia i ukarania sprawców lub przyznania odszkodowania stronie poszkodowanej.

Dalej zaznaczono: „Definicja ta ma na celu wyłączenie innych czynności, które mogą być podejmowane w innych celach, na przykład w celu ustalenia prawdy historycznej” (§ 143). Wydaje się prima facie, że zdanie to może zostać odczytane jako pozostawiające dociekania, co jest prawdą historyczną w sprawie zbrodni katyńskiej poza pojęciem czynności natury proceduralnej, których ocena mieści się w zakresie jurysdykcji Trybunału. Przyjąć trzeba jednakże, iż nie było chyba intencją Trybunału twierdzenie, że czynności proceduralne mogą być prowadzone w oderwaniu od prawdy historycznej i przynosić rezultaty z nią sprzeczne, niepodlegające jego ocenie, albowiem chodzi o ustalenie prawdy co do sprawców umyślnego pozbawienia życia, a więc zabójstw, o których mówi art. 2 otwierający konwencję jako najcięższym naruszeniu praw człowieka. Przyjąć przeto raczej należy, że, zdaniem Trybunału, ustalenie prawdy historycznej nie może być jedynym celem czynności proceduralnych i że mają one prowadzić do wykrycia sprawców, jak również ich ukarania. Zauważyć przy tym trzeba, iż jakkolwiek prawda historyczna o tej zbrodni jest powszechnie znana, to jednak chodzi współcześnie o to, jak pozwane państwo kwalifikuje zachowania ustalonych sprawców kategoriach prawa, albowiem jeżeli z obowiązku proceduralnego określonego w art. 2 konwencji wynika powinność podjęcia czynności prowadzących do ustalenia sprawców zabójstw, to jednocześnie konieczne jest określenie kwalifikacji prawnokarnej ich czynów. W rosyjskim stanowisku przedstawionym Trybunałowi mowa jest o przekroczeniu uprawnień, bez wskazania sprawców i wykonawców bez-

zagadnienia właściwości temporalnej. W wyroku tym przyjęto, że w przypadku śmierci, do której doszło przed dniem ratyfikacji, to jest „datą graniczną”, właściwość temporalna Trybunału może obejmować tylko proceduralne działania i zaniechania państwa, do których doszło po tej dacie. Musi przy tym istnieć „rzeczywisty związek” między śmiercią a przyjęciem przez to państwo konwencji. Ustalono, że „rzeczywisty związek” zachodzi, jeżeli czas od śmierci do daty granicznej jest racjonalnie krótki, to znaczy nie upłynęło więcej niż dziesięć lat. Właściwość temporalna Trybunału obejmuje tylko zasadniczą część śledztwa, która została przeprowadzona lub powinna zostać przeprowadzona po przyjęciu przez państwo konwencji. Znaczy to, że Trybunał nie ocenia śledztwa w sprawie zabójstwa, jeżeli zarówno ten akt, jak i główna część śledztwa miały miejsce w czasie, zanim państwo ratyfikowało konwencję. W szczególnym przypadku, jeżeli brak jest „rzeczywistego związku”, Trybunał może wyjątkowo przyjąć swą jurysdykcję opartą na konieczności zapewnienia, by gwarancje i wartości, które legły u podstaw konwencji, były stosowane i przestrzegane w rzeczywisty i skuteczny sposób („klauzula humanitarna”). 
prawnie wydawanych poleceń zamordowania polskich jeńców wojennych, z równoczesnym zanegowaniem, że miało miejsce ludobójstwo. Przypuszczać można, że treść utajnionego dokumentu końcowego zamykającego śledztwo nie zawiera przekonującego uzasadnienia stwierdzenia, iż Rosja wywiązała się z obowiązku przeprowadzenia rzetelnego śledztwa i tym samym wypełniła obowiązki proceduralne wynikające $\mathrm{z}$ art. 2 konwencji. Natomiast na podstawie jego treści można by wskazać wszystkie zaniechania, które miały miejsce w przedmiotowej sprawie. Zasadniczego znaczenia nabiera w tym miejscu pytanie, czy Trybunał oceniłby je w kategoriach naruszenia przez pozwane państwo konwencyjnej powinności.

Wątpliwość w tym względzie wynika $\mathrm{z}$ fragmentu wywodu, w którym Trybunał stwierdził, że „Federacja Rosyjska ratyfikowała konwencję w dniu 5 maja 1998 r., czyli 58 lat po rozstrzelaniu krewnych skarżących", co sprawia, że okres który upłynął od śmierci do daty granicznej, jest ,zbyt długi dla ustalenia rzeczywistego związku między śmiercią krewnych skarżących a wejściem w życie Konwencji w stosunku do Rosji” (§ 157). Dalej przypomniano, że śledztwo w sprawie masowych grobów zostało rozpoczęte w 1990 r. i ,nawet jeśli rosyjski Rząd powołuje się na błąd proceduralny związany z wszczęciem postępowania to przynajmniej teoretycznie śledztwo miało doprowadzić do wykrycia i ukarania sprawców”. Jako takie „mieściło się ono w zakresie »działań i zaniechań proceduralnych « zgodnie z art. 2 Konwencji” (§ 158). Wszystkie ważne kroki proceduralne, takie jak ekshumacja ciał z masowych grobów w Charkowie, Miednoje i Katyniu, badania przeprowadzone przez biegłych, przesłuchania ,potencjalnych” świadków egzekucji, spotkania robocze z udziałem władz rosyjskich, polskich ukraińskich i białoruskich, miały miejsce przed datą graniczną, to jest przed ratyfikacją konwencji przez Rosję. Natomiast po ratyfikacji 5 maja 1998 r. „nie podejmowano jakichkolwiek rzeczywistych kroków proceduralnych" wymaganych dla stwierdzenia, że istnieje „,rzeczywisty związek” między nimi a śmiercią osób, których krewni zwrócili się do Trybunału ze skargą na Rosję. Trybunał ocenił, że „nie kwalifikuje się jako ważna część kroków proceduralnych” po dacie granicznej nowa ocena dowodów, wnioski odmienne od wniosków uprzednich czy też decyzja o utajnieniu części akt śledztwa nr 159 (§ 159). Nasuwa się w tym miejscu uwaga, że — zdaniem Trybunału — to właśnie niepodjęcie po ratyfikacji konwencji „ważnych kroków proceduralnych”, o których mowa w jej art. 2, uchyla możliwość egzekwowania od Rosji obowiązków wynikających z tego przepisu. Ponadto — zaznaczono — nie pojawił się żaden istotny dowód ani nie została ujawniona żadna istotna dla sprawy informacja. Zapytać przeto trzeba, jak miałby skądinąd „pojawić” się nowy dowód lub ,istotna informacja” bez prowadzenia czynności proceduralnych w śledztwie, które faktycznie zatrzymano. Odnośnie do stwierdzenia, że nie kwalifikuje się jako ważny krok proceduralny wydanie decyzji o utajnieniu części akt śledztwa, zauważyć trzeba, że dla Rosji właśnie „ważną decyzją proceduralną" było wydanie i objęcie tajemnicą treści postanowienia 
o umorzeniu śledztwa. Było i pozostaje tak dlatego, że w dokumencie kończącym postępowanie powinno zostać zapisane, jak niebudzące wątpliwości fakty historyczne zostały po przyjęciu przez Rosję konwencji ocenione w kategoriach prawnych, wskazani imiennie wykryci sprawcy — decydujący i wykonawcy zbrodni, określony zakres odpowiedzialności każdego z nich i podane, dlaczego żaden nie został oskarżony. Dopiero zapoznanie się z tym dokumentem pozwoliłoby Trybunałowi na udzielenie wiarygodnej odpowiedzi, czy Rosja dopełniła obowiązku proceduralnego wynikającego $\mathrm{z}$ art. 2 konwencji. $\mathrm{Z}$ tych względów zdumiewać musi konkluzja, że nie można ustalić „rzeczywistego związku” tego, co działo się $\mathrm{w}$ śledztwie po ratyfikacji konwencji z wydarzeniem pierwotnym jako warunku jego jurysdykcji temporalnej ${ }^{26}$.

Patrząc z historycznej perspektywy, uzasadniona wydaje się refleksja, że zaniechanie kontynuowania śledztwa po ratyfikacji konwencji i jego tajne w swym uzasadnieniu zakończenie miało zapewnić Rosji, że jej własne organy prokuratorskie i sądowe nie sformułują innej kwalifikacji tej zbrodni aniżeli banalnej w swej semantyce w kategoriach przedawnionego w 1950 r. nadużycia urzędniczego i że nie dojdzie do oceny zbrodni katyńskiej na gruncie prawa międzynarodowego, co sprawi, iż państwo to zabezpieczy się przed wszelką odpowiedzialnością za

${ }^{26}$ Krytyka tego stwierdzenia została sformułowana we wspólnym zdaniu odrębnym czterech sędziów, którzy podnieśli, że śledztwo nr 159 trwało aż do wydania w 2004 r. postanowienia o jego umorzeniu i przez cały ten okres miało istotne braki, zawierało sprzeczności i zakończyło się w całkowitej tajemnicy. Arbitralne twierdzenie władz rosyjskich, że śledztwo prowadzono bez podstawy prawnej ,z powodów politycznych, jako gest dobrej woli w stosunku do władz polskich" określone został jako „nie do obrony”. Tak samo arbitralna była odmowa rehabilitacji ofiar zbrodni. Postępowanie władz Rosji nie spełniało wymogów art. 2 konwencji. Podkreślone zostało, że nie można przyjąć argumentu rządu rosyjskiego, iż w czasie popełnienia tej zbrodni wojennej nie istniały żadne wiążące przepisy międzynarodowego prawa humanitarnego zawierające definicję odpowiedzialności za zbrodnie wojenne i zbrodnie przeciwko ludzkości. W owym czasie obowiązywało zwyczajowe prawo międzynarodowe skodyfikowane w IV konwencji haskiej z $1907 \mathrm{r}$. oraz konwencji genewskiej z 1929 r. Zagłada polskich jeńców wojennych w 1940 r. stanowiła naruszenie zakazu zbrodni wojennych i zbrodni przeciwko ludzkości. Państwo rosyjskie miało obowiązek badania tej zbrodni i ścigania jej sprawców. Obowiązek ten nie ma limitu czasowego, gdyż zbrodnie wojenne i zbrodnie przeciwko ludzkości nie ulegają przedawnieniu. Zaznaczono, że organy państwowe zaprzeczały istnieniu jakiegokolwiek związku lub odpowiedzialności za zbrodnię katyńską przez ponad czterdzieści lat. Podkreślono, że „Prawo do prawdy jest żywotną gwarancją przeciwko ponownym naruszeniom i chroni wspólną pamięć osób dotkniętych, co stanowi część jego dziedzictwa". W podsumowaniu stwierdzono, że Trybunał powinien uznać swoją jurysdykcję ratione temporis $\mathrm{w}$ rozpatrywanej sprawie na tej podstawie, że istniał „,rzeczywisty związek", o którym mowa w wyroku Šilih. Odnotowano przy tym, że sprawa Šilih dotyczyła śmierci będącej wynikiem błędu medycznego, podczas gdy rozpatrywana sprawa dotyczy mordu ponad 21 tys. polskich jeńców wojennych. Do tej uwagi dodano jednak, że zasady regulujące jurysdykcję Trybunału muszą być takie same dla wszystkich spraw. Zdanie odrębne sędziów I. Ziemele, V.A. de Gaetano, J. Laffranque i H. Keller, § 4-29. 
jej popełnienie. Na to, że cel ten został współcześnie osiągnięty, wskazuje kolejna sekwencja uzasadnienia referowanego wyroku.

W odrębnej części wywodu Trybunał rozważył, czy uzasadnione byłoby odstąpienie od wymogu „rzeczywistego związku” przez zastosowanie standardu wartości konwencji. Jest to możliwe, jeżeli „zdarzenie powodujące” obowiązek prowadzenia skutecznego śledztwa miało znacznie szerszy wymiar niż zwykły czyn zagrożony karą, jak również było sprzeczne z samymi podstawami konwencji. Uściślono dalej, że,,za takie zdarzenia należy uznać poważne zbrodnie przeciwko prawu międzynarodowemu, takie jak zbrodnie wojenne, ludobójstwo lub zbrodnie przeciwko ludzkości” (§ 150). Zbrodnie te według prawa międzynarodowego nie mogą być poddane jakimkolwiek przepisom prawa krajowego o przedawnieniu ich karalności. Jednakże, stwierdził Trybunał, kryterium „wartości Konwencji" nie może mieć zastosowania do wydarzeń, które miały miejsce przed przyjęciem konwencji w dniu 4 listopada 1950 r., albowiem dopiero od tego momentu rozpoczęła ona swój byt jako międzynarodowy traktat praw człowieka. Twierdzenie mające zasadnicze znaczenie dla wyroku Trybunału zawarte zostało w zdaniu:

Umawiająca się Strona nie może być odpowiedzialna na gruncie Konwencji za nieprzeprowadzenie śledztwa w sprawie najpoważniejszych nawet zbrodni prawa międzynarodowego, jeżeli miały one miejsce przed przyjęciem Konwencji (§ 151).

Po tym stwierdzeniu wskazane zostało, iż Trybunał rozumie argument podniesiony przeciwko Rosji, że „,nawet obecnie niektóre państwa z powodzeniem osądziły sprawców zbrodni wojennych popełnionych podczas drugiej wojny światowej”. Podkreślił jednak „fundamentalną różnicę” między możliwością postawienia w stan oskarżenia za poważną zbrodnię przeciwko prawu międzynarodowemu tam, gdzie pozwalają na to okoliczności a byciem zobowiązanym do tego na mocy konwencji (§ 151). W ten sposób Trybunał stwierdził, że na Rosji, która w 1998 r. ratyfikowała konwencję z 1950 r., nie ciąży konwencyjny obowiązek rozliczenia się $\mathrm{w}$ formie śledztw ze zbrodni popełnionych przed tą datą.

We wniosku końcowym zamykającym wywód stwierdzono, że nie było w tej sprawie żadnego elementu, który mógłby posłużyć jako pomost łączący odległą przeszłość z ostatnim okresem datującym się od wejścia w życie konwencji w stosunku do Rosji jako państwa pozwanego (§ 160). Stosunkiem trzynastu głosów do czterech Trybunał orzekł, że ,podtrzymuje zarzut przedwstępny Rządu w zakresie właściwości ratione temporis i stwierdza, że nie posiada właściwości do rozpatrzenia skargi na podstawie art. 2 Konwencji” (§ 161 ${ }^{27}$. Podnieść jednakże

27 W zdaniu odrębnym wskazano, że rozpatrywana sprawa doskonale nadawała się do zastosowania „klauzuli humanitarnej” wskazanej w wyroku Šilih. Klauzula ta pozwala Trybunałowi uznać swoją właściwość w sprawach dotyczących poważnych naruszeń praw człowieka, czyli do takich wydarzeń, które wyczerpują znamiona zbrodni wojennych, ludobójstwa i zbrodni przeciwko 
w tym miejscu trzeba, że konkluzja ta podważa racje przedstawionego powyżej, jednomyślnego stwierdzenia przez sędziów Trybunału, że rząd Rosji nie wywiązał się z obowiązków ciążących na nim na podstawie art. 38 konwencji nakazującego państwu udzielenie „wszelkich niezbędnych ułatwień” dla podjętego przez Trybunał dochodzenia i rozpatrzenia sprawy. Wszak Trybunał od samego początku postępowania wiedział, że zbrodnia katyńska została popełniona w pierwszej połowie drugiego roku drugiej wojny światowej - 10 lat przed przyjęciem konwencji. Jeżeli więc $\mathrm{z}$ tego powodu — zgodnie $\mathrm{z}$ twierdzeniem rosyjskiego rządu - Trybunał uznał się za niekompetentny do rozpatrzenia przedmiotu skargi, to sam zanegował procesową podstawę dla żądania od Rosji „udzielenia ułatwień” do przeprowadzenia dochodzenia. Jeżeli Trybunał nie uznał ani decyzji o zakończeniu śledztwa, ani o jego utajnieniu za „ważne kroki proceduralne”, to dlaczego odmowę udostępnienia takiego „nieistotnego” dokumentu końcowego potraktował jako niedopełnienie przez Rosję obowiązku współdziałania wynikającego z art. 38 konwencji (§ 152). Poszukiwanie racjonalnej prawniczo odpowiedzi na takie nasuwające się pytanie nie przynosi pozytywnego rezultatu.

Deklaracja braku jurysdykcji ze strony Trybunału, stanowiąca przyznanie racji pozwanej Rosji, jest potwierdzeniem procesowej skuteczności konsekwentnej strategii tego państwa negującego właściwość międzynarodowej sprawiedliwości w odniesieniu do własnych działań. Przypomnieć trzeba, że w procesie norymberskim rosyjski prokurator gen. R.A. Rudenko (główny oskarżyciel ZSRR) upomniał Trybunał, zarzucając mu brak kompetencji do zbadania treści tajnego protokołu stanowiącego załącznik do paktu o nieagresji między Niemcami a Związkiem Sowieckim, zawartego 23 sierpnia 1939 r. Treść protokołu wskazywała jednoznacznie na to, że III Rzesza i ZSRR byli uczestnikami spisku, w ramach którego strony uzgodniły współdziałanie w napaści na Polskę i podział jej terytorium między siebie, stanowiącego zbrodnię przeciwko pokojowi. Prokurator Rudenko zaprotestował przeciwko badaniu przez trybunał tej sprawy, mówiąc: „Ja chcę zaprotestować przeciwko temu [...] my badamy sprawę zbrodni głównych niemieckich zbrodniarzy wojennych. My nie prowadzimy śledztwa [w sprawie] polityki zagranicznej innych państw"28. Protest okazał się skuteczny, ponieważ ten aspekt sprawy, kto obok Niemiec był drugą stroną spisku przeciwko pokojowi, którego

ludzkości. Twierdzenie Trybunału, że nie może jej zastosować do zdarzeń, które miały miejsce przed przyjęciem Konwencji 4 listopada 1950 r., budzi sprzeciw. Taka interpretacja „klauzuli humanitarnej" zamyka drogę postępowania przed Trybunałem ofiarom wszelkich poważnych naruszeń praw człowieka, które miały miejsce przed opracowaniem konwencji. Podkreślono, że obecnie „,jest wyraźnie akceptowane, że zainteresowane państwa mają obowiązek proceduralny ustalenia faktów, odnalezienia sprawców i ukarania ich". Przez to, że Trybunał nie zastosował w rozpatrywanej sprawie „klauzuli humanitarnej”, pozbawił ją „,skutku humanitarnego” i jednocześnie osłabił jej znaczenie na przyszłość. Zdanie odrębne sędziów I. Ziemele, V.A. de Gaetano, J. Laffranque i H. Keller, § 30-35.

28 Więcej W. Kulesza, Zbrodnia katyńska..., s. 429. 
zawiązanie poprzedziło napaść na Polskę i wybuch wojny, nie znalazł swego odzwierciedlenia w wyroku norymberskiego Trybunału.

Drugi zarzut uczyniony przez skarżących pozwanemu państwu polegał na tym, że przedłużające się zaprzeczanie faktom historycznym oraz zatajenie informacji o losie ich bliskich, jak również lekceważące i sprzeczne odpowiedzi władz rosyjskich na ich wnioski o informacje stanowiły nieludzkie i poniżające traktowanie, sprzeczne z art. 3 konwencji ${ }^{29}$. W uzasadnieniu skargi podnoszono, że rosyjskie władze zaprzeczały faktom historycznym, uznając zamordowanych za „zaginionych”, co zadawało skarżącym dotkliwe cierpienie, ból i stres. Twierdzenie prokuratorów rosyjskich, że nie można ustalić, ,,jaki przepis kodeksu karnego stanowił podstawę prawną do pociągnięcia [polskich] więźniów do odpowiedzialności", w gruncie rzeczy stanowiło krzywdzące domniemanie, że ofiary były przestępcami skazanymi na karę śmierci zgodnie z prawem. Przytoczona została wypowiedź prokuratora w postępowaniu rehabilitacyjnym przed moskiewskim sądem, że istniały powody do takiego traktowania, gdyż niektórzy polscy oficerowie byli „szpiegami, terrorystami i sabotażystami $(\S 174)^{30}$.

Argument pozwanej Rosji o braku możliwości ustalenia przepisu karnego stanowiącego podstawę prawną „do pociągnięcia więźniów do odpowiedzialności" jawi się w kategoriach semantycznej perwersji języka prawniczego, ponieważ w poleceniu z 5 marca 1940 r. napisano, że sprawy polskich jeńców i więźniów „zostaną rozpoznane w trybie specjalnym, z zastosowaniem najwyższego wymiaru kary — rozstrzelanie", zaznaczając, że ma to nastąpić bez przedstawienia im zarzutów i aktu oskarżenia. Ten fragment polecenia znany był Trybunałowi i przytoczony został na wstępie jego wyroku, w części Fakty. Tło sprawy (§ 18), co dało asumpt do stwierdzenia, że członkowie politbiura „zatwierdzili przeprowadzenie pozasądowej egzekucji polskich jeńców wojennych, której mieli dokonać funkcjonariusze NKWD” (§ 153). Dlatego podkreślić trzeba, że z cytowanego polecenia wynika jednoznacznie, iż nie chodziło o „pociągnięcie do odpowiedzialności" w sensie choćby elementarnych zasad prawa karnego, lecz rozstrzelanie „wrogów władzy sowieckiej”, która ich uwięziła i nakazała zamordowanie.

29 Art. 3 konwencji: „Nikt nie może być poddany torturom ani nieludzkiemu lub poniżającemu traktowaniu".

$30 \mathrm{~W}$ trakcie rozprawy przed Sądem Miejskim w Moskwie 22 stycznia 2009 r. odmowa rehabilitacji osób, których zwłoki zidentyfikowano w wyniku niemieckiej ekshumacji w Katyniu w 1943 r., a także zidentyfikowanych podczas ekshumacji w 1991 r. w Miednoje, przeprowadzonej z udziałem rosyjskich i polskich prokuratorów, uzasadniona została tym, że ustalenie danych osobowych w wyniku ekshumacji zbiorowych grobów osób nie świadczy, że „wobec ustalonych osób zastosowano represje polityczne”. Sędzia stwierdził dalej, że „otwór od kuli w czaszce świadczy o skorzystaniu z broni palnej, ale niekoniecznie o rozstrzelaniu człowieka", jako represji politycznej. Bez odpowiedzi sędzia ten pozostawił argument, że w każdym z odkrytych zbiorowych grobów znajdowało się co najmniej kilkaset zwłok i wszystkie miały przestrzelone czaszki. A. Gurjanow, op. cit., s. 105-106. 
Współczesne poszukiwanie przepisu karnego jawi się więc jako próba usprawiedliwienia zbrodni, a jego nieodnalezienie podawane jest na uzasadnienie odmowy uznania zamordowanych za ofiary represji politycznej ${ }^{31}$. Niełatwo jest przy tym znaleźć określenie, które we właściwy sposób oddawałoby historyczną i prawną naturę tego argumentu. Trudno przyjąć, że stanowisko Rosji wynika z braku zdolności zrozumienia tego, co napisano o polskich jeńcach i więźniach w poleceniu ich rozstrzeliwań z 5 marca 1940 r. i co w ówczesnych warunkach jednoznacznie wyznaczało przepis karny, którego współcześnie rzekomo nie można było ustalić, albowiem w poleceniu jest mowa o polskich jeńcach wojennych i więźniach jako o ,członkach polskich nacjonalistycznych kontrrewolucyjnych partii, członkach ujawnionych kontrrewolucyjnych organizacji powstańczych, byłych oficerach, urzędnikach, obszarnikach policjantach, żandarmach, służby więziennej i agentach wywiadu”. Stwierdza się, że jeńcy przebywający w obozach „próbują kontynuować działalność kontrrewolucyjną" i „prowadzą antysowiecką agitację”, a aktywną rolę kierowniczą odgrywają byli oficerowie byłej polskiej armii, byli policjanci i żandarmi. Wśród więźniów są zbiegowie i osoby, które naruszyły państwowe granice, w znacznej liczbie wykryci członkowie różnorakich organizacji kontrrewolucyjnych, szpiegowskich, dywersyjnych i powstańczych. Dwukrotnie w dokumencie wszyscy jeńcy i więźniowie określeni są jako ,zawzięci wrogowie władzy sowieckiej”, „pełni nienawiści do ustroju sowieckiego”, z zaznaczeniem, że nie rokują poprawy, co czyni „niezbędne” zastosowanie „wobec nich najwyższego wymiaru kary — rozstrzelanie". W świetle powszechnej wiedzy o działaniu NKWD, któremu zlecono wykonanie tego zadania, jest oczywiste, że posłużono się, dla czysto formalnego uzasadnienia poleconych masowych egzekucji, przepisami zawartymi w art. 58 rosyjskiego kodeksu karnego z 1926 r. Przepis ten otwierał rozdział pierwszy części szczególnej tego kodeksu i na wstępie definiował przestępstwa kontrrewolucyjne:

Za kontrrewolucyjne uważa się każde [wsiakoje] działanie skierowane na obalenie, podważenie lub osłabienie władzy rad robotniczo-chłopskich przyznanych im na podstawie konstytucji Związku SSR [...] lub podważenie bezpieczeństwa wewnętrznego związku ZSRR i podstawowych, gospodarczych, politycznych i narodowych zdobyczy rewolucji proletariackiej.

W części oznaczonej jako art. 58-11 ustanowiona została karalność „,Wszelkiego rodzaju [wsiakogo roda] działalności organizacyjnej skierowanej na przygotowanie lub dokonanie przestępstw przewidzianych w tym rozdziale, a także udział w organizacji utworzonej dla przygotowania lub dokonania takich przestępstw",

31 Według Memoriału ustawa o rehabilitacji nie zawiera warunku, aby rehabilitacja była przeprowadzona wyłącznie na podstawie sprawy karnej wszczętej przeciw osobie represjonowanej. Rosyjskie sądy odrzucały jednak wszystkie wnioski Memoriału o rehabilitację rozstrzelanych. Ibidem, s. 107. 
z zastrzeżeniem, że za takie zachowanie ma zostać wymierzona kara przewidziana za dokonanie. Poprzedzający ten przepis art. 58-10 stanowił o karalności, do kary śmierci włącznie, ,propagandy lub agitacji dla obalenia, podkopania lub osłabienia władzy sowieckiej lub dla popełnienia jednego z przestępstw przewidzianych w tym rozdziale”. Kara śmierci następowała także za: „okazanie, jakim by to nie było sposobem pomocy tej części międzynarodowej burżuazji, która nie uznaje za równoprawny system komunistyczny, przychodzący aby zastąpić system kapitalistyczny" (art. 58-4), jak również szpiegostwo, które mogło polegać na samym zbieraniu informacji jawiących się ze względu na treść jako tajne w celu przekazania kontrrewolucyjnym organizacjom lub osobom prywatnym (art. 58-6), kontrrewolucyjny sabotaż (art. 58-14), uczestniczenie w aktach „terrorystycznych” przeciw przedstawicielom sowieckiej władzy, „,chociażby osoby uczestniczące nie należały do organizacji kontrrewolucyjnej" (art. 58-8). Ten, kto sam nie podpadał pod żaden z przepisów o przestępstwie kontrrewolucyjnym, podlegał za niedoniesienie o jego przygotowywaniu lub popełnieniu karze pozbawienia wolności do 10 lat, a w okolicznościach obciążających „nie powyżej 25 lat” — art. 58-12 w zw. z art. $28^{32}$. Podkreślić trzeba z naciskiem, że rosyjski kk. z 1926 r. przewidywał także karalność na zasadzie analogii czynów społecznie niebezpiecznych, nieprzewidzianych wprost $\mathrm{w}$ tym kodeksie [diejstwie priamo nie priedusmotrienno nastojaszczim Kodeksom] — art. 16. W takich przypadkach podstawy i zakres kary określał ten artykuł kodeksu, który przewidywał najbardziej zbliżony rodzaj przestępstwa [najbol'ie schodnyje po rodu priestuplienja]. A zatem rozstrzelanie, w zgodzie z tym kodeksem, mogło nastąpić także za to, co nie zostało wprost przewidziane w art. 58, w tych wszystkich przypadkach, gdy jego treść była „,najbardziej zbliżona" do zachowania tych, których polecano rozstrzelać. Twierdzenie pozwanej Rosji, że jej prokuratura, pomimo tej historycznej, powszechnej wiedzy, nie mogła ustalić, na podstawie jakiego przepisu karnego jeńcy i więźniowie „zostali pociągnięci do odpowiedzialności", uznać trzeba za prawniczo cyniczne $i$ jednocześnie obraźliwe, a przez to poniżające krewnych ofiar zbrodni, co zapewne byłby zmuszony skonstatować strasburski Trybunał, gdyby uznał się za właściwy do merytorycznego rozpatrzenia ich skargi. Podkreślić trzeba z naciskiem, że według wiedzy historycznej „trójka wykonawcza” NKWD, której polecono sporządzić listy polskich jeńców i więźniów przeznaczonych do rozstrzelania, nie dokonywała własnej oceny polecenia i innej ,subsumcji” osób pod przepisy rosyjskiego kodeksu karnego z 1926 r., lecz zgodnie z zasadą, że zlecone jej zadanie musi być

32 Wiedza i pamięć o stosowaniu przez NKWD art. 58 KK z 1926 r. były i pozostają powszechne w rosyjskim społeczeństwie, stąd bierze się obiegowe powiedzenie, że kanał Wołga-Don zbudowali łagiernicy, którzy zostali skazani za wypowiedź przy wieczornym piciu wódki z innymi, choćby żartobliwą o władzy radzieckiej lub realiach życia [szutniki — żartownisie], uznaną za antysowiecką propagandę (art. 58-10), a także ci, którzy następnego dnia zaspali [sónji — śpiochy] i rano nie zdążyli, jako pierwsi, donieść o takiej wypowiedzi organom bezpieczeństwa (art. 58-12). 
wykonane „bezwzględnie, ściśle i w terminie” zapewne przytoczyła właśnie artykuł 58 tego kodeksu o „wszelkich działaniach kontrrewolucyjnych”. Dla uznania współcześnie, że zarządzone przez nią egzekucje stanowiły represje polityczne, nie jest istotne, które części tego art. 58 powołane zostały w stosunku do poszczególnych osób zamordowanych, ponieważ wszystkie traktowały o „przestępstwach kontrrewolucyjnych", dając podstawy do karania także innych zachowań w nich „wprost nie przewidzianych”. Dlatego oczywiste jest, iż dla stwierdzenia przez rosyjskie władze, że zamordowanie polskich jeńców i więźniów stanowiło takie represje, wystarczyłoby porównanie treści polecenia zawartego w uchwale z 5 marca 1940 r. z przepisami ówczesnego kodeksu karnego, czego nie uczyniono ani przed, ani po ratyfikacji konwencji. Trudne do zrozumienia jest przeto stanowisko Trybunału, według którego zaniechanie to, trwające do umorzenia śledztwa, mające uzasadnić odmowę uznania zamordowanych za ofiary represji politycznych, nie stanowiło istotnej czynności proceduralnej, która podlegałaby jego ocenie i czyniła go kompetentnym do rozpatrzenia skargi.

W pełni zrozumiałe jest natomiast uzasadnienie stanowiska skarżących, którzy podkreślali, że ich moralne cierpienie nie może być zakwalifikowane jako towarzyszące z natury zabójstwom jako takim, lecz wynikało z traktowania, jakiego doświadczyli ze strony władz rosyjskich.

W odpowiedzi na zarzuty rząd Rosji stwierdził, że los polskich jeńców i więźniów nie mógł zostać ustalony z pewnością wymaganą w postępowaniu karnym lub „rehabilitacyjnym”, ponieważ nie było wystarczających dowodów dla stwierdzenia związku przyczynowego między „wydarzeniami katyńskimi” a śmiercią krewnych osób skarżących. Mimo to krewni polskich jeńców wojennych nie znajdowali się w stanie niepewności co do tego, czy ich bliscy nadal żyją, ponieważ „nierozsądnym byłoby oczekiwać” że do 5 maja 1998 r., to jest ratyfikowania konwencji, pozostawali oni przy życiu, uwzględniając ich daty urodzenia i brak jakichkolwiek wiadomości od nich od czasu drugiej wojny światowej. Cierpienie skarżących określone zostało jako „nieuchronnie odczuwane przez krewnych osób, które stały się ofiarami poważnych naruszeń praw człowieka” i nie zostało zwiększone przez „dodatkowe czynniki”. Rząd stwierdził, że rosyjskie sądy nie zaprzeczały realiom historycznym, wskazywały „tylko na brak wystarczających dowodów pozwalających na ustalenie okoliczności śmierci krewnych osób skarżących”. Rosyjski rząd podkreślił na zakończenie, że nie miał intencji zniekształcenia faktów historycznych ani też poddania skarżących jakiejkolwiek formie poniżającego traktowania (§ 169-171).

Trybunał powtórzył, że jego jurysdykcja w rozpatrywanej sprawie rozciąga się jedynie na okres od daty 5 maja 1998 r., to jest wejścia w życie konwencji w stosunku do Rosji. Stwierdził następnie, że nie można uznać, by po tej dacie pozostawała długotrwała niepewność co do losu polskich jeńców wojennych. Pomimo że nie wszystkie ciała były ekshumowane, to jednak ich śmierć została publicznie 
uznana przez sowieckie i rosyjskie władze, stając się ustalonym faktem historycznym. W tym miejscu wywodu Trybunał uznał prawdę historyczną za decydującą o odmowie udzielenia ochrony skarżącym przed poniżającym traktowaniem, albowiem stwierdził, że dla skarżących śmierć ich krewnych była pewna, dlatego nie znajdowali się oni w długim okresie niepewności co do losu osób zaginionych. Natomiast istotą naruszenia art. 3 Konwencji jest lekceważący stosunek i nastawienie władz krajowych wobec krewnych, ciągły i bezduszny brak poszanowania obowiązku ustalenia losu osób zaginionych i udzielenia informacji. We wcześniejszym orzecznictwie Trybunału przyjęto, a w referowanym wyroku powtórzono, że cierpienie członków rodzin „osoby zaginionej” wynikające z długiego okresu przeplatających się ze sobą nadziei i rozpaczy może uzasadniać stwierdzenie naruszenia art. 3 konwencji przez władze krajowe, jeżeli bezdusznie odnoszą się one do wniosków o udzielenie informacji. Trybunał zaznaczył, że nie kwestionuje głębokiego żalu i bólu, których to uczuć skarżący doświadczyli wskutek pozasądowych egzekucji członków ich rodzin. W rozpatrywanej sprawie Trybunał uznaje „że nie może stwierdzić, aby cierpienie skarżących osiągnęło wymiar i charakter odmienny od emocjonalnego bólu, który można uznać za nieuchronnie odczuwany przez krewnych ofiar poważnych naruszeń praw człowieka” (§ 185-188).

Rozumowanie to wiodło Trybunał do orzeczenia, stosunkiem dwunastu głosów do pięciu, że nie doszło do naruszenia art. 3 konwencji.

Na kanwie całego wywodu zawartego w zreferowanym wyroku jego czytelnikowi nasunąć się może refleksja, że Trybunał stracił szansę wniesienia wkładu do wyznaczenia - w kategoriach praw człowieka — standardu ochrony dobra prawnego, jakim jest współcześnie pamięć zbiorowa. Dobro to, w jego szerokim znaczeniu, to notoryjna i utrwalona wiedza o faktach historycznych, determinujących w XX w. losy osób prześladowanych z powodów przynależności narodowej, rasowej lub wyznaniowej, które stały się ofiarami zbrodni wojennych i przeciwko ludzkości, popełnionych w imię urzeczywistnienia w Europie ideologii nazistowskiej lub komunistycznej. Pamięć zbiorowa jest współcześnie źródłem motywacji obywateli i uzasadnieniem dla obrony godności człowieka zakotwiczonej w konstytucji każdego demokratycznego państwa prawnego. Do utrzymania konstytucyjnego porządku prawnego opartego na poszanowaniu godności człowieka konieczny jest sprzeciw obywateli wobec każdego naruszenia ich ludzkich praw, a historyczne ratio takiego sprzeciwu wynika z pamięci zbiorowej o przeszłości, w której godność ludzka była poniżana przez totalitarną władzę. Potrzeba ochrony pamięci zbiorowej uzasadnia prawnokarne zakazy publicznego propagowania ideologii nazistowskiej lub komunistycznej, a także publicznego zaprzeczania zbrodniom dokonanym przez władze państwowe odwołujące się do tych ideologii ${ }^{33}$.

33 Więcej W. Kulesza, Wadliwe kody pamięci a zbiorowa pamięć jako dobro społeczne chronione prawem karnym, [w:] Wadliwe kody pamięci. Zniekształcenie pamięci o zbrodniach międzynarodowych w dyskursie publicznym, red. A. Nowak-Far, Ł. Zamęcki, Warszawa 2015, s. 162. 
Na treść art. 38 konwencji, zakazującego poniżającego traktowania człowieka, spojrzeć można z perspektywy ochrony pamięci w ścisłym znaczeniu, na które to dobro prawne składają się wiedza i przeżycia pokolenia ofiar, uczestników i świadków zdarzeń, przekazywane w drodze „spadku pamięci” ich dzieciom i wnukom, w okresie życia trzypokoleniowych rodzin. Zakres czasowy ochrony pamięci, sięgając wstecz, obejmuje współcześnie to, czego doświadczyło pokolenie ofiar zbrodni popełnionych w okresie drugiej wojny światowej, co sprawia, że zstępni zamordowanych mają prawo do ochrony przed poniżającym traktowaniem przez państwo, którego władze zdecydowały o dokonaniu tych zbrodni. Konwencja o ochronie praw człowieka i podstawowych wolności z 1950 r. odwołuje się w swej preambule do Powszechnej deklaracji praw człowieka z 1948 r., ta zaś we wstępie mówi, że

brak poszanowania i pogarda dla praw człowieka doprowadziły do aktów barbarzyństwa, które wstrząsnęły sumieniem ludzkości, a nadejście świata, w którym ludzie będą korzystać z wolności słowa i przekonań oraz wolności od strachu i niedostatku, ogłoszono jako najwznioślejszy cel człowieka.

Stało się tak zatem w wyniku trwania pamięci o zbrodniach popełnionych w okresie drugiej wojny i to ona jest racją uzasadniającą powołanie Europejskiego Trybunału Praw Człowieka stojącego na straży postanowień konwencji. Można by przeto oczekiwać, że Trybunał uzasadni objęcie ochroną wynikającą z art. 38 konwencji także uczucia osób wynikające z pamięci o ich bliskich zamordowanych w okresie trwania tej wojny. Postępowanie władz rosyjskich wobec krewnych polskich jeńców wojennych, odmowa uznania ich za ofiary państwowej zbrodni i sugerowanie, że mogli oni zostać skazani za popełnione przez nich przestępstwa, stawiają skarżących w upokarzającym położeniu jako członków rodzin tych, których bliscy — zdaniem współczesnego rosyjskiego wymiaru sprawiedliwości być może zasłużyli na ukaranie ich śmiercią. Takie pohańbienie pamięci zamordowanych jest pośrednim naruszeniem godności ich bliskich, stanowiącym istotę odniesienia się przez Rosję do wszystkich, wielokrotnie powtarzanych ich próśb. Skonstatować trzeba przeto, że w przedmiotowej sprawie Rosja naruszyła uczucie pietyzmu, którym otaczają oni swych zamordowanych bliskich, i poniżająco ich potraktowała, co spowodowało zwrócenie się do Trybunału o ochronę przed takim traktowaniem, ustanowioną w treści art. 3 konwencji. W wyroku Trybunału nie znajdujemy jednak jego jurystycznej empatii ze skarżącymi, ponieważ za lekceważące potraktowanie go przez Rosję odmawiającą udostępnienia mu zamykającego śledztwo postanowienia o umorzeniu śledztwa w sprawie zbrodni katyńskiej potępił on pozwane państwo, powołując art. 38 konwencji, jednocześnie stwierdzając, że takie samo zachowanie wobec krewnych ofiar zbrodni i pasmo upokorzeń, których doznali oni ze strony jej władz prokuratorskich i sądowych, nie daje podstawy do potępienia w świetle art. 3 konwencji. Dlatego stwierdzić trzeba, 
że Trybunał odmówił ochrony dobru prawnemu, jakim współcześnie jest pamięć zbiorowa i wynikające z niej uczucie pietyzmu otaczające ofiary barbarzyństwa drugiej wojny światowej, bez którego poszanowania idea sprawiedliwości może zostać zwiedziona na manowce niekompetencji organów powołanych do jej urzeczywistnienia. Przygnębiające jest to, iż precedensowe orzeczenie strasburskiego Trybunału odbiera nadzieję członkom rodzin ofiar zbrodni katyńskiej na to, że międzynarodowa justycja zrozumie ich racje i obejmie ochroną pamięć o ofiarach zbrodni nieukaranej i ludzką godność tych, którzy o niej nie zapomnąa ${ }^{34}$.

\section{The Katyń massacre before the European Court of Human Rights - reflections on the October 21, 2013 judgment}

\section{Summary}

Both the Nuremberg Tribunal in its judgment of Jan. 1, 1946 as well as the European Court of Human Rights' Grand Chamber judgment of Oct. 21, 2013 in the case of Janowiec and Others v. Russia abstracted from a substantive decision on Russia's responsibility for the Katyn massacre and failed to determine the consequences to be borne by the defending state, whose authorities decided upon the performance of the act in question. Contemporary Russian state denies that the murder of 22,000 Polish prisoners of war and inmates at the behest of the highest authorities of the USSR in 1940 was indeed a war crime. According to the position of the Russian government, represented before the ECHR, what took place was solely a crime committed by the administrative personnel who acted beyond their authority, the prosecution of which expired after 10 years, i.e. in 1950. The Russian side also claimed that it was not obliged to conduct an investigation on the matter and refused to disclose the content of the order to discontinue the criminal proceedings issued in 2004 to both the relatives of those who were murdered and to the ECHR. It also refused to recognize the murdered Polish prisoners of war as victims of political repression, claiming that it is unclear according to which criminal code they were sentenced to be shot. Russia's position in denying the temporal jurisdiction of the ECHR and the ratione materiae with regard to the Katyn massacre which was in fact accepted by the ECHR in its judgment, should be subject to criticism. According to the statement of the court, Russia has not violated Article 2 of the Convention in its procedural aspect or Article 3 in its way of dealing with the relatives of the victims. The Court has lost the chance to contribute to appointing — in terms of human rights — a protection standard for a vital legal interest, which is currently the collective memory of the persecution of people because of their national, racial or religious background, ones who had become victims of war crimes and crimes against humanity, committed in the name of Nazi or communist ideology once pursued in Europe.

Keywords: Katyń massacre, international humanitarian law, human rights.

34 Jurystyczna gorycz zauważana jest w konkluzji zdania odrębnego sędziego K. Wojtyczka, który podniósł, że sprawa została przekazana do Wielkiej Izby na wniosek skarżących (vide przypis nr 2 niniejszego tekstu). Sędzia ten skonstatował: „Wprawdzie Konwencja nie artykułuje zakazu reformatio in peius, sytuacja jest o tyle paradoksalna, że środek prawny przewidziany $\mathrm{w}$ art. 43 Konwencji wykorzystany przez skarżących w celu zapewnienia ochrony praw człowieka w rezultacie doprowadził do wyroku Wielkiej Izby, który jest dla nich znacznie mniej korzystny niż wyrok Izby". 